\title{
Nitrogen transformation among char, tar and gas during pyrolysis of sewage sludge and corresponding hydrochar
}

\author{
Tingting Liu ${ }^{\mathrm{a}, \mathrm{b}}$, Yanchuan Guo ${ }^{\mathrm{c}, \mathrm{d}}$, Nana Peng ${ }^{\mathrm{a}, \mathrm{b}}$, Qianqian Lang ${ }^{\mathrm{a}, \mathrm{b}}, \mathrm{Yu} \mathrm{Xia}^{\mathrm{a}, \mathrm{b}}$, Chao Gai ${ }^{\mathrm{a}, \mathrm{b}}$, \\ Zhengang $\mathrm{Liu}^{\mathrm{a}, \mathrm{b}, *}$ \\ a Research Center for Eco-Environmental Sciences, Chinese Academy of Sciences, Beijing 100085, China \\ ${ }^{\mathrm{b}}$ University of Chinese Academy of Sciences, Beijing 100049, China \\ ${ }^{\mathrm{c}}$ Key Laboratory of Photochemical Conversion and Optoelectronic Material, Technical Institute of Physics and Chemistry, Chinese Academy of Sciences, Beijing 100190, \\ China \\ ${ }^{\mathrm{d}}$ Hangzhou Branch of Technical Institute of Physics and Chemistry, Chinese Academy of Sciences, Hangzhou 310018, China
}

\section{A R T I C L E I N F O}

\section{Keywords:}

Sewage sludge

Hydrothermal carbonization

Hydrochar

Pyrolysis

$\mathrm{NH}_{3}$

$\mathrm{HCN}$

\begin{abstract}
A B S T R A C T
Hydrothermal carbonization (HTC) is a promising thermochemical pretreatment to convert sewage sludge into the hydrochar prior to combustion or pyrolysis for energy generation. To investigate the effects of HTC on nitrogen transformation behaviors, pyrolysis of sewage sludge and the corresponding hydrochar were conducted. The results showed nitrogen in the hydrochar existed in more stable forms, making more nitrogen retained in the char for the hydrochar pyrolysis. Amine- $\mathrm{N}$, heterocyclic- $\mathrm{N}$ and nitrile- $\mathrm{N}$ were detected in significant amounts for sewage sludge pyrolysis tar, which contributed to predominant $\left(\mathrm{NH}_{3}+\mathrm{HCN}\right)-\mathrm{N}$ emission. Lower amine- $\mathrm{N}$ and heterocyclic- $\mathrm{N}$ content but higher alkyl nitrile- $\mathrm{N}$ content were observed in the hydrochar pyrolysis tar, which might explain the increase in $\mathrm{HCN} / \mathrm{NH}_{3}$ ratio. More importantly, the $\left(\mathrm{NH}_{3}+\mathrm{HCN}\right)-\mathrm{N}$ yield from the hydrochar pyrolysis was considerably lower than that from sewage sludge pyrolysis, especially at temperatures higher than $650{ }^{\circ} \mathrm{C}$. Taking account of the much lower nitrogen content, the total $\left(\mathrm{NH}_{3}+\mathrm{HCN}\right)-\mathrm{N}$ emission from the hydrochar pyrolysis was only $35.6-48.2 \%$ of that from sewage sludge pyrolysis. The results suggested that HTC pretreatment of sewage sludge for energy production has the additional environmental benefit of mitigating nitrogenous pollutants emission.
\end{abstract}

\section{Introduction}

Sewage sludge, embedded with nearly all kinds of pollutants ranging from organic chemicals, heavy metals to pathogens, is increasing with rapid increase of wastewater treatment capacity [1,2]. As traditional methods of sewage sludge disposal including ocean dumping, landfill and land application are phasing out due to environmental issues and public concerns, efficient and environmental benign technologies should be developed for urgent challenge in sewage sludge disposal [3].

Combustion of sewage sludge is an excellent and proven disposal way, which can immobilize heavy metals in the solid residue, depredate highly toxic persistent organic compounds and reduce sewage sludge volume excellently as well as recovery energy $[4,5]$. However, high nitrogen content of sewage sludge supports the release of either $\mathrm{NO}_{x}$ or $\mathrm{N}_{2} \mathrm{O}$ from combustion [6,7]. $\mathrm{NO}_{x}$ are main contributors to photochemical smog and acid rain, while $\mathrm{N}_{2} \mathrm{O}$ will aggravate global warming and ozone layer depletion [8]. Pyrolysis is another attractive thermochemical conversion method to convert sewage sludge into biooil, combustible gas and the biochar [6]. Bio-oil and combustible gas can be used as potential chemical feedstocks and fuels and the biochar has been widely applied as either fuels or functional materials $[9,10]$. In addition, pyrolysis is the primary stage of the combustion, and understanding nitrogen conversion mechanisms during pyrolysis helps to reduce $\mathrm{NO}_{x}$ discharge in combustion process [11]. Consequently, extensive studies related to sewage sludge pyrolysis have been carried out over years. It has been demonstrated $\mathrm{HCN}$ and $\mathrm{NH}_{3}$ were mainly originated from the second cracking of nitrogen-containing compounds including amine- $\mathrm{N}$, pyrrole- $\mathrm{N}$, pyridine- $\mathrm{N}$ and nitrile-N [6,9-14]. Increasing heating rate and shortening residence time decreased the emission of both $\mathrm{NH}_{3}$ and $\mathrm{HCN}$ while increasing temperature facilitated $\mathrm{NH}_{3}$ and HCN emission [6,9,12,13]. Additionally, iron/calcium-containing minerals were reported to catalyze the conversion of fuel-N/ $\mathrm{NH}_{3}$ into $\mathrm{N}_{2}$ at high temperature $[6,9,15]$. By means of the analysis in terms of nitrogen existing forms and distribution, the nitrogen migrating pathways during sewage sludge pyrolysis were established and

\footnotetext{
* Corresponding author at: Research Center for Eco-Environmental Sciences, Chinese Academy of Sciences, Beijing 100085, China

E-mail address: zgliu@rcees.ac.cn (Z. Liu).
} 
controlling intermediates generation was believed to be favorable in reducing $\mathrm{NH}_{3}$ and $\mathrm{HCN}$ emission [6,9-11].

In addition to the emission of nitrogenous contaminants, the high moisture content and poor dewaterability of sewage sludge also limit the wide application of combustion and pyrolysis in disposing sludge due to energy-intensive drying process. Hydrothermal carbonization (HTC) is a notable thermochemical treatment which not only improve sludge dewaterability and but also convert sludge into a homogenized hydrochar with high energy density [16-18]. Moreover, HTC has the additional benefit of reducing nitrogen content through hydrolysis and deamination [19-21]. The outstanding advantages of HTC have made it increasingly important to convert sewage sludge into the hydrochar $[18,22,23]$. Nevertheless, more than $50 \%$ of nitrogen is still left in the hydrochar after HTC treatment of sewage sludge [20]. To control $\mathrm{NO}_{x}$ or its precursors emission during the hydrochar conversion requires better insight into the nitrogen transformation mechanism during hydrochar pyrolysis. However, related study is seriously insufficient compared to sewage sludge.

In the present study, nitrogen transformation during sewage sludge and corresponding hydrochar pyrolysis were investigated comparably. Specifically, the contribution of char- $\mathrm{N}$ and tar- $\mathrm{N}$ to $\mathrm{NH}_{3}$ and $\mathrm{HCN}$ emission was evaluated and the effects of HTC and pyrolysis temperature on nitrogen distribution and nitrogenous compounds in the tar were determined. Furthermore, nitrogen conversion pathways of sewage sludge and the hydrochar during pyrolysis were also proposed. The purpose of this study is to investigate the effects of HTC on nitrogen transformation behaviors, which in turn provide possible strategy to reduce $\left(\mathrm{NH}_{3}+\mathrm{HCN}\right)$ and $\mathrm{NO}_{x}$ emission, and ultimately realize clean disposal of sewage sludge.

\section{Experimental methods}

\subsection{Materials}

In this study, digested sewage sludge was obtained from a wastewater treatment plant in Shandong Province. The digested sewage sludge (moisture content of $81 \%$ ) was dried at $105^{\circ} \mathrm{C}$ for $24 \mathrm{~h}$ and then crushed. The particles of 100-150 mesh were used for the pyrolysis in the present study.

The hydrochar was prepared through HTC of digested sewage sludge (without drying) using a stainless steel autoclave reactor equipped with thermocouple, pressure gauge and stirrer (Fig. 1). About $1.5 \mathrm{~kg}$ of raw sludge was loaded into the reactor and based on our preliminary experiment, the reactor was heated up to $200{ }^{\circ} \mathrm{C}$ holding
Table 1

Characteristics of sewage sludge and the hydrochar (average \pm standard deviations).

\begin{tabular}{|c|c|c|c|}
\hline & & Sewage sludge & Hydrochar \\
\hline \multirow[t]{3}{*}{$\begin{array}{l}\text { Proximate analysis } \\
\text { (wt. } \%, \mathrm{db})\end{array}$} & $\begin{array}{l}\text { Fixed } \\
\text { carbon }\end{array}$ & $8.13 \pm 0.20$ & $10.13 \pm 0.3$ \\
\hline & $\begin{array}{l}\text { Volatile } \\
\text { matter }\end{array}$ & $49.01 \pm 0.30$ & $31.33 \pm 0.30$ \\
\hline & Ash & $42.86 \pm 0.30$ & $58.54 \pm 0.36$ \\
\hline \multirow{5}{*}{$\begin{array}{l}\text { Ultimate analysis } \\
\qquad(w t . \%, d b)\end{array}$} & $\mathrm{C}$ & $26.67 \pm 0.18$ & $23.40 \pm 0.30$ \\
\hline & $\mathrm{N}$ & $4.00 \pm 0.03$ & $2.06 \pm 0.06$ \\
\hline & $\mathrm{H}$ & $3.25 \pm 0.33$ & $2.36 \pm 0.30$ \\
\hline & S & $1.17 \pm 0.00$ & $1.10 \pm 0.00$ \\
\hline & $\mathrm{O}^{\mathrm{a}}$ & $22.05 \pm 0.45$ & $12.54 \pm 0.53$ \\
\hline \multirow[t]{2}{*}{ Atomic ratio } & $\mathrm{H} / \mathrm{C}$ & 1.46 & 1.21 \\
\hline & $\mathrm{O} / \mathrm{C}$ & 0.62 & 0.40 \\
\hline \multirow{7}{*}{$\begin{array}{l}\text { Metals contents } \\
\qquad\left(\mathrm{mg} \mathrm{kg}^{-1}, \mathrm{db}\right)\end{array}$} & $\mathrm{K}$ & $4722.00 \pm 56.67$ & $4479.98 \pm 60.49$ \\
\hline & $\mathrm{Ca}$ & $3314.39 \pm 34.80$ & $4400.19 \pm 59.36$ \\
\hline & $\mathrm{Na}$ & $6340.87 \pm 90.20$ & $4180.66 \pm 3.24$ \\
\hline & $\mathrm{Mg}$ & $6123.93 \pm 64.13$ & $7782.18 \pm 40.44$ \\
\hline & $\mathrm{Al}$ & $20411.40 \pm 92.91$ & $28901.70 \pm 99.20$ \\
\hline & $\mathrm{Fe}$ & $22384.10 \pm 142.94$ & $30371.00 \pm 234.91$ \\
\hline & $\mathrm{Ni}$ & $2078.51 \pm 24.93$ & $2841.71 \pm 28.21$ \\
\hline
\end{tabular}

Notes: db-dry basis.

${ }^{\text {a }}$ Calculated by difference.

for $30 \mathrm{~min}$. After cooling the reactor down to ambient temperature, the solid-liquid mixture in the reactor was separated by vacuum centrifuge and the resultant solid residue was recovered as the hydrochar. Then the hydrochar was dried at $105^{\circ} \mathrm{C}$ for $24 \mathrm{~h}$ and ground as raw sludge did. The dried hydrochar was weighed before stored in sealing bags for use. The main chemical properties of dried sewage sludge and the hydrochar are listed in Table 1.

\subsection{Pyrolysis experiment}

The pyrolysis of sewage sludge and the hydrochar were performed on a fixed-bed tubular reactor with a quartz tube of $1500 \mathrm{~mm}$ in length and $55 \mathrm{~mm}$ in inner diameter (Fig. 1). In each experiment, $3.0 \mathrm{~g}$ of fuel sample was loaded into a quartz boat and then was placed inside of the quartz tube appropriately. The quartz tube was pushed into the heating zone at the desired temperature $\left(350-950{ }^{\circ} \mathrm{C}\right.$ in an increment of $150{ }^{\circ} \mathrm{C}$ ). After $30 \mathrm{~min}$ pyrolysis at final temperature, the quartz tube was pushed out of the heating zone and cooled down to ambient temperature using an electric fan. During the whole pyrolysis, a $500 \mathrm{~mL} \mathrm{~min}^{-1}$ of $\mathrm{N}_{2}$ was introduced to maintain an inert atmosphere.
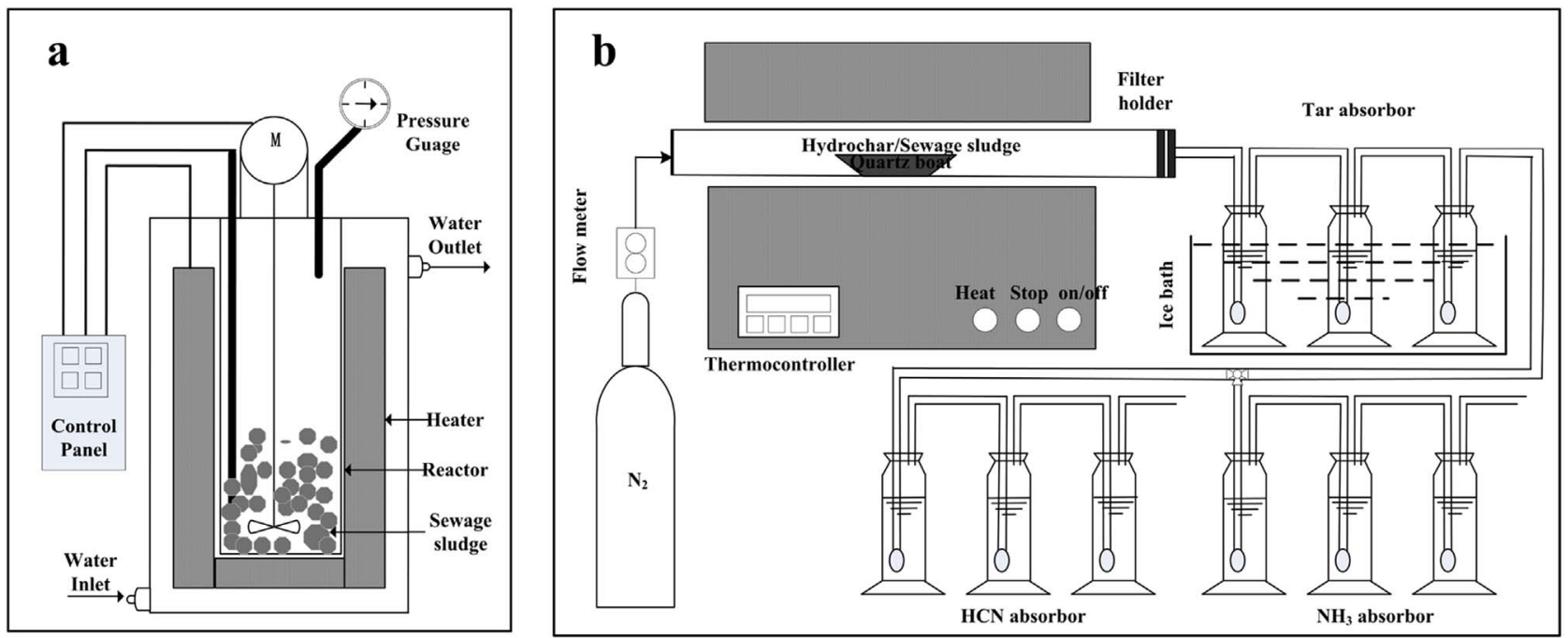

Fig. 1. Schematic diagram of the hydrothermal carbonization (a) and pyrolysis process (b). 
The char in the quartz boat was weighed and its nitrogen content was determined. The pyrolysis tar was collected by the absorption bottle containing dichloromethane in an ice bath and was weighed carefully by removing all dichloromethane. The gas yield was obtained by the difference. The principal nitrogenous gas, $\mathrm{HCN}$ and $\mathrm{NH}_{3}$, were absorbed using $0.20 \mathrm{~mol} \mathrm{~L}^{-1} \mathrm{NaOH}$ solution and $0.10 \mathrm{~mol} \mathrm{~L}^{-1} \mathrm{H}_{2} \mathrm{SO}_{4}$ solution, respectively. Separate runs for collecting $\mathrm{NH}_{3}$ and $\mathrm{HCN}$ were conducted because $\mathrm{HCN}$ and $\mathrm{NH}_{3}$ have non-negligible solubility in $\mathrm{H}_{2} \mathrm{SO}_{4}$ and $\mathrm{NaOH}$ solutions, respectively (Fig. 1). Triplicate experiments were carried out at least for each condition to guaranty the reliability and repeatability of the results.

\subsection{Analysis methods}

The element contents of the char and tar were determined using an element analyzer (Vario EL III, Elementar). The metals contents in sewage sludge and the hydrochar were measured by inductively coupled plasma optical emission spectrum (ICP-OES, Prodigy, Leeman) [24]. The morphology was assessed by scanning electron microscope (SEM, S-4800, HITACHI). The functional groups in sewage sludge and the hydrochar were examined using Fourier Transform infrared spectroscopy (FTIR, Nicolet 8700, Thermo Fisher Scientific). X-ray photoelectron spectroscopy (XPS, ESCALAB $250 \mathrm{Xi}$, Thermo Fisher Scientific) was used to analyze the chemical nature of $\mathrm{N}$ in sewage sludge and the hydrochar. All XPS spectra were obtained under identical condition. To compensate for the sample charging, the binding energy (BE) of samples was referenced to the C 1 s peak at $284.6 \mathrm{eV}$. The XPS areas were fitted using least-squares method based on Gauss-Lorentzian shapes (XPSPEAK 4.1), with a Shirley type background. The fitted areas of peaks reflected the relative contents of different $\mathrm{N}$-containing compounds, which were normalized according to the total nitrogen contents in samples for semiquantitative comparisons.

The $\mathrm{HCN}$ and $\mathrm{NH}_{3}$ absorbed in the solution were quantified by $\mathrm{HJ}$ 484-2009 and HJ 535-2009 methods, respectively [9]. The nitrogenous compounds in the tar were identified by GC-MS using an Agilent 7890A-5975C coupled with a HP-5 MS column $(30 \mathrm{~m} \times 0.25 \mathrm{~mm} \times 0.25 \mu \mathrm{m})$. All the tar samples passed through $1 \mathrm{~cm}$ anhydrous sodium sulfate column and $0.22 \mu \mathrm{m}$ organic filter membrane prior to GC-MS analysis. The purified tar samples $(10 \mu \mathrm{L})$ were injected into the gas chromatograph under splitless conditions. The oven was programed to hold a constant temperature at $40{ }^{\circ} \mathrm{C}$ for $4 \mathrm{~min}$, heat up at rate of $4{ }^{\circ} \mathrm{C} \mathrm{min}{ }^{-1}$ to $300{ }^{\circ} \mathrm{C}$, and then hold steady for $15 \mathrm{~min}$. Data were collected in the full scan mode and the peaks were identified from the NIST database. The relative contents of nitrogenous compounds were normalized through the percentage of the individual peak area to the total peak area in ion chromatogram [6].

\section{Results and discussion}

\subsection{Characteristics of sewage sludge and the hydrochar}

Ultimate analysis and proximate analysis (Table 1) revealed the effects of HTC on characteristics of sewage sludge. The fixed carbon content increased from $8.13 \%$ to $10.13 \%$ and volatile matter decreased by $18 \%$. Both oxygen and nitrogen contents reduced by around $50 \%$ accompanied by $28 \%$ of hydrogen removal due to the dehydration and decarboxylation reactions. This gave rise to a decrease of $\mathrm{H} / \mathrm{C}$ ratio and $\mathrm{O} / \mathrm{C}$ ratio from 1.46 to 1.21 and from 0.62 to 0.40 , respectively. The hydrochar was close to the region of lignite $(\mathrm{H} / \mathrm{C}$ and $\mathrm{O} / \mathrm{C}$ atomic ratios of lignite are generally $0.8-1.3$ and $0.2-0.38$, respectively), suggesting the higher carbonization and better fuel quality of the hydrochar than sewage sludge $[16,18]$. The minerals were also considered due to the strong influences on pyrolysis behaviors. As illustrated in Table 1, most examined metals were concentrated in the hydrochar and especially for iron which increased from $22384 \mathrm{mg} \mathrm{kg}^{-1}$ in sewage sludge to $30371 \mathrm{mg} \mathrm{kg}^{-1}$ in the hydrochar.

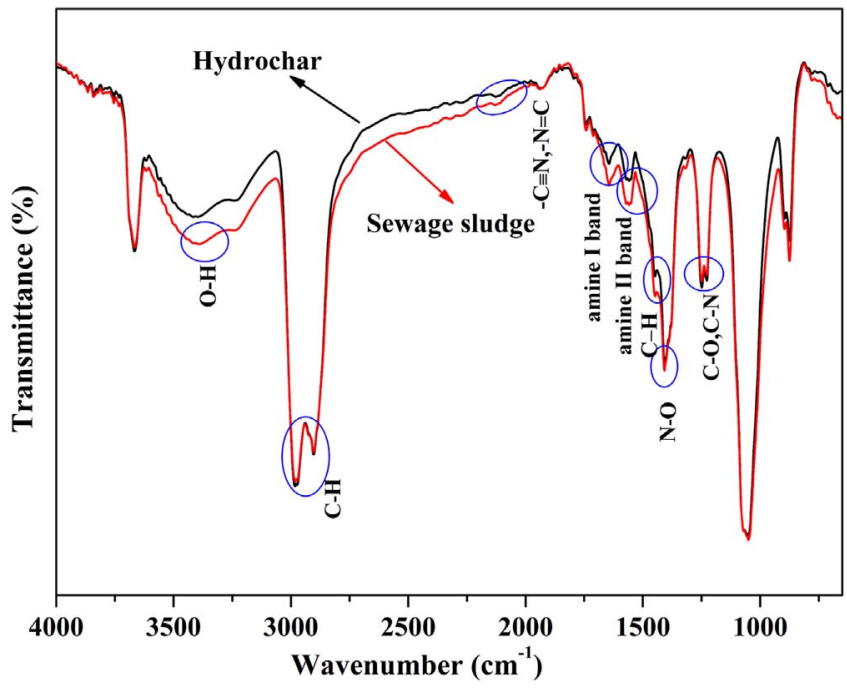

Fig. 2. FTIR spectra for sewage sludge and the hydrochar.

The FTIR spectra of sewage sludge and the hydrochar are presented in Fig. 2. Some characteristic adsorptions of nitrogen-containing functional groups were observed at $1655 \mathrm{~cm}^{-1}$ (C-O stretching of amide I bond), $1555 \mathrm{~cm}^{-1}$ (N-H stretching of amide II bond), $1408 \mathrm{~cm}^{-1}$ ( $\mathrm{N}-\mathrm{O}$ bonding in nitrite), $2120 \mathrm{~cm}^{-1}(\mathrm{C} \equiv \mathrm{N}$ stretching of nitrile or $\mathrm{N}=\mathrm{C}$ stretching of isonitrile) and $1570 \mathrm{~cm}^{-1}(\mathrm{C}-\mathrm{N}$ stretching of heterocyclic-N) in sewage sludge $[13,21,25]$. In addition, the strong bands at $2800-3000 \mathrm{~cm}^{-1}$ and $1450 \mathrm{~cm}^{-1}$ can be attributed to $\mathrm{C}-\mathrm{H}$ stretching and bending of aliphatic, respectively, and the peaks at $2970 \mathrm{~cm}^{-1}$ and $2900 \mathrm{~cm}^{-1}$ may be derived from aliphatic carbon $\mathrm{C}-\mathrm{H}$ stretching in cellulose $[17,21]$. Compared to sewage sludge, notable reduction of the peaks at $1655 \mathrm{~cm}^{-1}, 1555 \mathrm{~cm}^{-1}$ and $1570 \mathrm{~cm}^{-1}$ were observed for the hydrochar, which was associated with the decreased content of nitrogen due to the hydrolysis of organic-N and the release of inorganic-N into water during HTC process $[17,20]$. Furthermore, a decrease in the peak at $1450 \mathrm{~cm}^{-1}$ was observed, indicating the lower degree of aliphaticity of the hydrochar compared to sewage sludge.

The change in nitrogen existing forms was also determined by $\mathrm{N} 1 \mathrm{~s}$ spectra (Fig. 3) and normalized peak intensities (\%) of sewage sludge and the hydrochar are shown in Table S1. The N 1s spectra of sewage sludge exhibited four peaks, including inorganic-N (ammonium or nitrate salts), pyrrole-N, protein-N and pyridine-N. After HTC treatment, inorganic-N was removed and protein-N decreased from $38.03 \%$ to $25.57 \%$. In addition, nitrile-N appeared after HTC, which might originate from the dehydrogenation of amine- $\mathrm{N}$ [20]. As the peaks of binding energy of protein-N and pyridine- $\mathrm{N}$ were higher in the hydrochar than those in sewage sludge (Fig. 3), higher activation energy was required for the decomposition of nitrogen in the hydrochar. The above analysis indicated the remarkable impact of HTC not only on nitrogen content but also on nitrogen functional groups in sewage sludge.

\subsection{Product distribution during pyrolysis of sewage sludge and the hydrochar}

The product yields of char and tar under various temperatures were calculated and reported as a percent (\%) based on the input sewage sludge/hydrochar while the gas yields were obtained by the difference (Fig. 4). The char yields exhibited a linear decline accompanying with continuous increase in gas yields with increasing temperature. The tar yields reached the maximum value of $14.8 \%$ and $8.8 \%$ for sewage sludge and the hydrochar at $500{ }^{\circ} \mathrm{C}$, respectively, and then decreased continuously with further increasing temperature. It could be seen that tar and gas yields for the hydrochar pyrolysis were much lower, but the char yields were higher than sewage sludge pyrolysis. The differences 

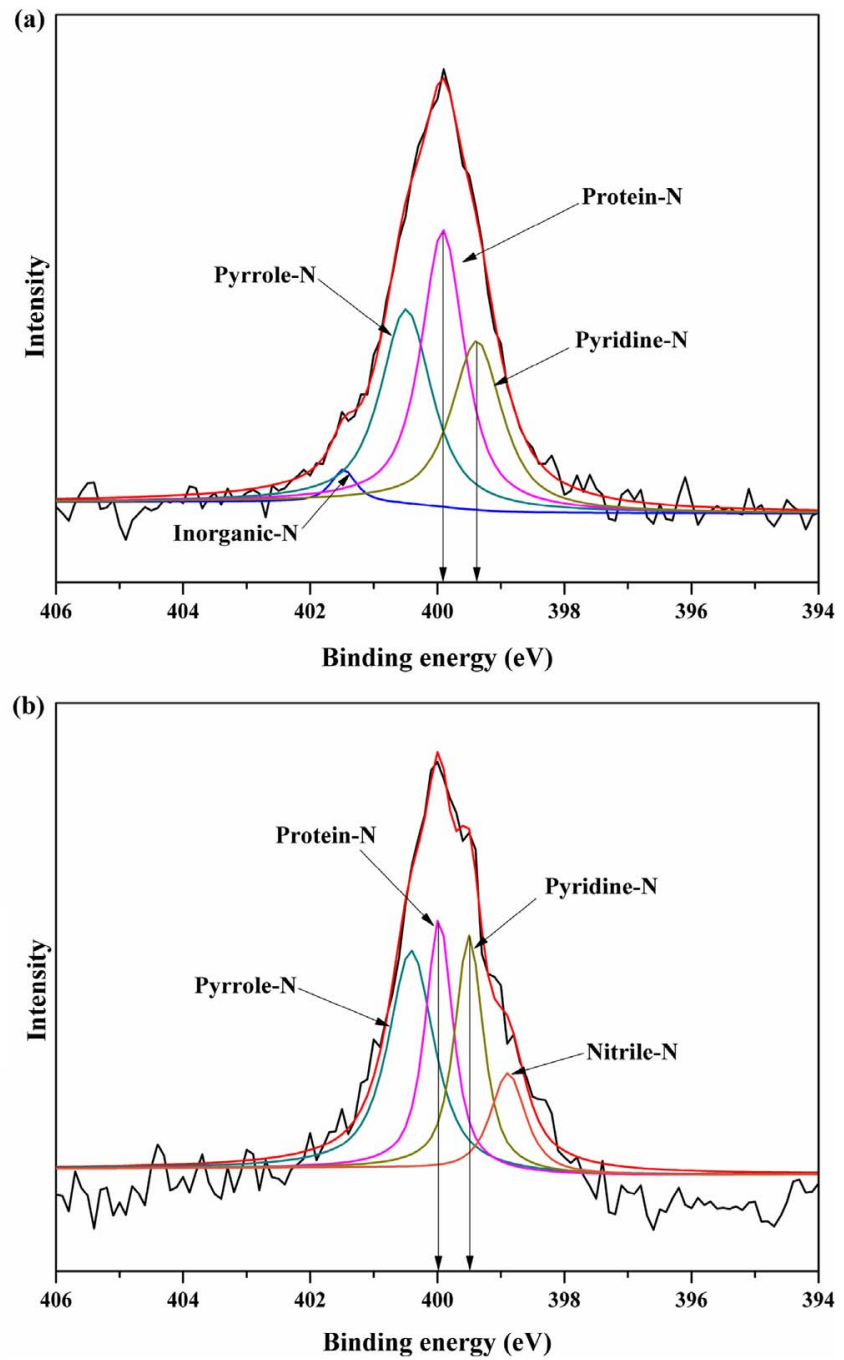

Fig. 3. N 1s spectra of sewage sludge (a) and the hydrochar (b).

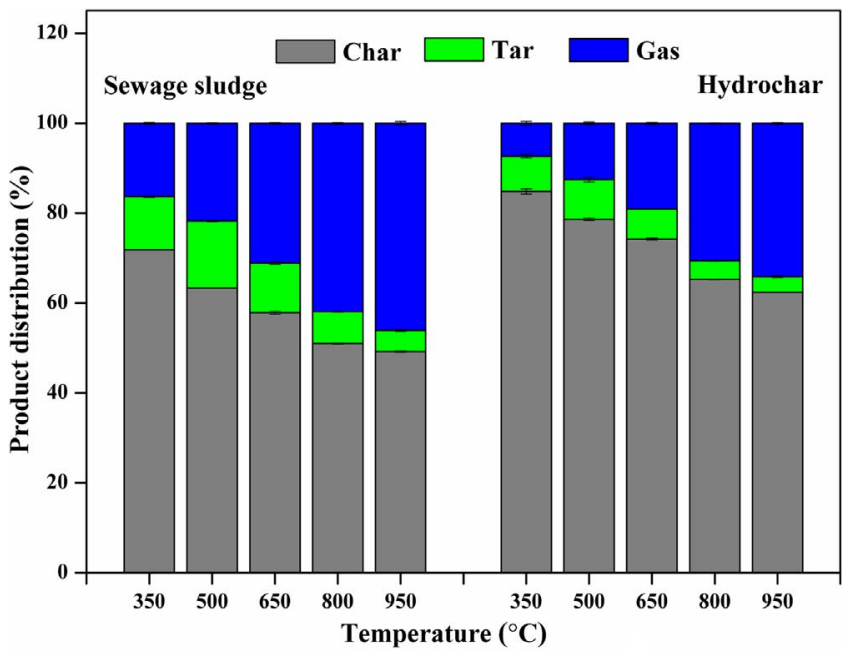

Fig. 4. The product distribution during sewage sludge and the hydrochar pyrolysis.

were potentially caused by low volatile matters and high ash content of the hydrochar [14].

\subsection{Nitrogen distribution in char and tar during pyrolysis}

The char- $\mathrm{N}$ and tar- $\mathrm{N}$ presented the nitrogen (\%) contained in char and tar based on total input fuel-N, respectively (Fig. 5). C/N ratios of the char and tar as a function of pyrolysis temperature are also illustrated in Fig. 5. It could be seen that increasing temperature facilitated the decomposition of char-N. However, the char-N yields from the hydrochar pyrolysis $(56.1-8.8 \%)$ were much higher than that from sewage sludge pyrolysis (51-4.5\%) under identical conditions. In addition, the increase in $\mathrm{C} / \mathrm{N}$ ratio for sewage sludge char was faster than that for the hydrochar char in the range of $500-950{ }^{\circ} \mathrm{C}$ (Fig. 5b). These differences demonstrated lower reactivity of nitrogen in the hydrochar char compared to that in sewage sludge char. Thus, less nitrogen released from char into tar or gas during the hydrochar pyrolysis was expected.

Fig. $5 c$ describes the effects of pyrolysis temperature on tar-N yields. Within examined temperature range, tar- $\mathrm{N}$ changed in a parabolic trend similar to that of tar yields. For sewage sludge, tar-N yields increased from $25.85 \%$ at $350{ }^{\circ} \mathrm{C}$ to $32.03 \%$ at $500{ }^{\circ} \mathrm{C}$, which was greatly attributed to the enhanced pyrolysis of protein- $\mathrm{N}$ and the secondary release of char- $\mathrm{N}$ [10]. With further increasing temperature from $500{ }^{\circ} \mathrm{C}$ to $950{ }^{\circ} \mathrm{C}$, tar-N yield dropped sharply from $32.03 \%$ to $9.1 \%$ due to the decomposition of relatively stable nitrogenous compounds into small molecular nitrogen-containing gas via ring opening reaction $[6,15]$. As for the hydrochar, tar-N yields were much lower than that of sewage sludge, which increased from $16.46 \%$ at $350{ }^{\circ} \mathrm{C}$ to $22.9 \%$ at $500{ }^{\circ} \mathrm{C}$ and then declined sharply to $8.3 \%$ at $950{ }^{\circ} \mathrm{C}$. In addition, the decomposition of tar- $\mathrm{N}$ from sewage sludge was much faster (Fig. $5 \mathrm{c}$ ) and $\mathrm{C} / \mathrm{N}$ of the tar declined continuously (Fig. 5d). This observation suggested thermal stability of tar-N from the hydrochar might be higher than that from sewage sludge. Moreover, the dehydration reaction and removal of volatile during HTC resulted in the cracks and fractures on the rough surface of hydrochar as show in Fig. S1. Hence, it was deduced that the second cracking of tar- $\mathrm{N}$ was suppressed during hydrochar pyrolysis as the residence time was shortened [26]. Therefore, nitrogen was more prone to transfer into tar for sewage sludge, while it was more prone to remain in the char for the hydrochar.

\subsection{The analysis of nitrogenous compounds in tar}

To reveal the contribution of tar- $\mathrm{N}$ to the $\mathrm{NH}_{3}$ and $\mathrm{HCN}$ emission, relative contents and species of these nitrogenous compounds in tar under various temperatures were determined and the results are shown in Tables 2 and S2-S4.

The nitrogenous organic compounds could be classified into amine$\mathrm{N}$ compounds, heterocyclic- $\mathrm{N}$ compounds and nitrile- $\mathrm{N}$ compounds $[11,13,27]$. For the tar from sewage sludge pyrolysis, amine-N content firstly increased from $2.56 \%$ to $5.22 \%$ by raising temperature from $350{ }^{\circ} \mathrm{C}$ to $500{ }^{\circ} \mathrm{C}$, and then decreased from $5.22 \%$ to $0.59 \%$ with increasing temperature to $950{ }^{\circ} \mathrm{C}$. As for the hydrochar pyrolysis, the amine- $\mathrm{N}$ content in the tar was much lower and reached the highest content of $1.04 \%$ at $800{ }^{\circ} \mathrm{C}$. In addition to the difference in amine- $\mathrm{N}$ content, amine- $\mathrm{N}$ species in the hydrochar tar also significantly differed from that in sewage sludge tar, especially in the temperature range of $350-650{ }^{\circ} \mathrm{C}$ (Table S2). Taking $350{ }^{\circ} \mathrm{C}$ and $500{ }^{\circ} \mathrm{C}$ for instance, 2-thiophenemethanamine and some oxygen-containing amine- $\mathrm{N}$ (amides) appeared in sewage sludge tar were absent in the hydrochar tar. This occurrence could be ascribed to the less volatile matters and the lower sulfur and oxygen contents in the hydrochar. Only aromatic amine-N was present at $800{ }^{\circ} \mathrm{C}$ and $950{ }^{\circ} \mathrm{C}$ pyrolysis for both sewage sludge and the hydrochar due to the higher thermal stability of aromatic structure.

According to Table 2, heterocyclic-N accounted for dominant nitrogenous compounds for both sewage sludge and the hydrochar. For sewage sludge, heterocyclic- $\mathrm{N}$ content increased significantly from $11.03 \%$ at $350{ }^{\circ} \mathrm{C}$ to $17.67 \%$ at $500{ }^{\circ} \mathrm{C}$ followed by a declination to $4.91 \%$ with further increasing temperature to $950{ }^{\circ} \mathrm{C}$. Similar changing trend in heterocyclic-N was observed for the hydrochar, which reached the peak of $6.98 \%$ at $500{ }^{\circ} \mathrm{C}$ followed by a decrease with further increasing temperature. It was believed that amine- $\mathrm{N}$ intermediates could 

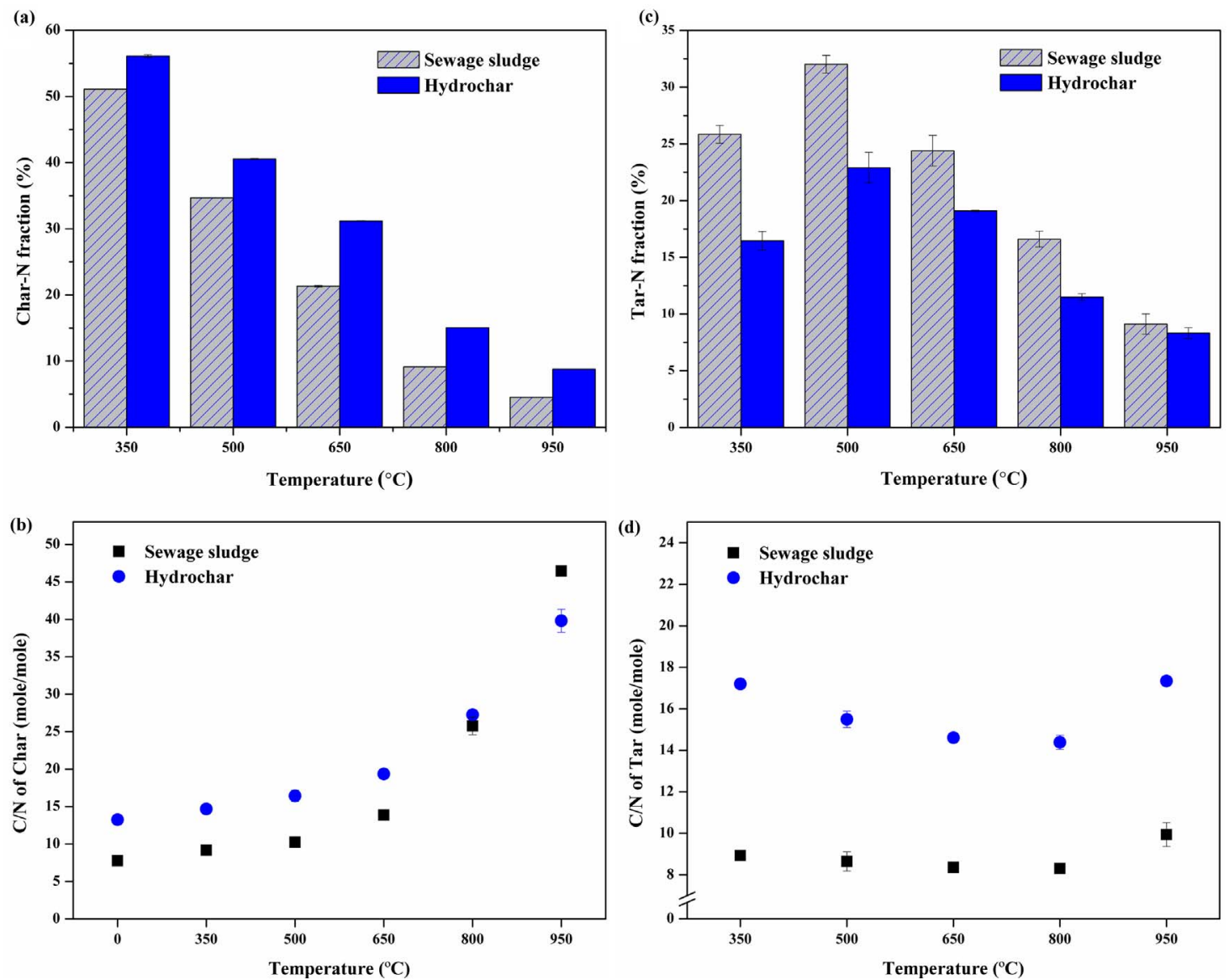

Fig. 5. The nitrogen fraction in char (a) and tar (c); the $\mathrm{C} / \mathrm{N}$ of char (b) and tar (d).

further generate heterocyclic- $\mathrm{N}$ and nitrile- $\mathrm{N}$ through secondary cracking reactions [6]. However, amine- $\mathrm{N}$ content at low temperature in the present study was rather low for the hydrochar, indicating that direct pyrolysis of char-N rather than the polymerization of amine- $\mathrm{N}$ was potentially responsible for heterocyclic-N compounds generation. Table S3 shows that the heterocyclic-N compounds were mainly composed of pyridines, quinolines (pyridine ring fused to benzene), pyrroles and indoles (pyrrole ring fused to benzene) as well as carbazoles (dibenzo-derivative of pyrrole), most of which have been identified in sewage sludge or biomass pyrolysis tars $[11,15,28-30]$. In addition, some nitrogenous compounds including acridine and quinoline with heteroaromatic ring were observed, which was also reported by Fullana et al. [31]. It was inferred that heterocyclic-N might be generated through similar mechanisms of PAHs formation, such as ring condensation reaction and Diels-Alder reaction $[6,12]$. In addition, temperature imposed apparent effects on both contents and species of heterocyclic-N in tar. For sewage sludge, the pyridines increased with increasing temperature and two-ring and three-ring structures were observed at temperature higher than $650{ }^{\circ} \mathrm{C}$. The quinolines appeared only at $800{ }^{\circ} \mathrm{C}$ and $950{ }^{\circ} \mathrm{C}$. The sum of pyrroles, indoles and carbazole firstly increased from $350{ }^{\circ} \mathrm{C}$ to $500{ }^{\circ} \mathrm{C}$ and then decreased sharply with further increasing temperature. Regarding to the hydrochar, both pyrroles and indoles contents were much lower than sewage sludge under the same pyrolysis conditions while differences of pyridines and quinolines contents were insignificant. This result indicated the higher thermal stability of hydrochar tar than sewage sludge tar since the pyridines and quinolines are more thermal stable than pyrroles and indoles [15]. Moreover, different from significant amount of carbazoles detected in sewage sludge tar at $500{ }^{\circ} \mathrm{C}$, carbazoles appeared mainly at $650{ }^{\circ} \mathrm{C}$ in the hydrochar tar.

As shown in Table 2, the nitrile- $\mathrm{N}$ content increased significantly when increasing temperature from $350{ }^{\circ} \mathrm{C}$ to $500{ }^{\circ} \mathrm{C}$, especially for the hydrochar tar. With increasing temperature from $500{ }^{\circ} \mathrm{C}$ to $950{ }^{\circ} \mathrm{C}$, nitrile-N decreased continuously for the hydrochar tar while increased at

Table 2

Nitrogen containing compounds in the tar from sewage sludge and the hydrochar pyrolysis (Normalized peak areas $\left(\mathrm{A}_{\mathrm{N}}\right)$, average \pm standard deviations)

\begin{tabular}{|c|c|c|c|c|c|c|c|c|c|c|}
\hline & \multicolumn{5}{|c|}{ Sewage sludge } & \multicolumn{5}{|c|}{ Hydrochar } \\
\hline & $350{ }^{\circ} \mathrm{C}$ & $500{ }^{\circ} \mathrm{C}$ & $650^{\circ} \mathrm{C}$ & $800{ }^{\circ} \mathrm{C}$ & $950{ }^{\circ} \mathrm{C}$ & $350{ }^{\circ} \mathrm{C}$ & $500{ }^{\circ} \mathrm{C}$ & $650^{\circ} \mathrm{C}$ & $800{ }^{\circ} \mathrm{C}$ & $950{ }^{\circ} \mathrm{C}$ \\
\hline Amine-N & $2.56 \pm 0.33$ & $5.22 \pm 0.24$ & $4.20 \pm 0.23$ & $2.88 \pm 0.30$ & $0.59 \pm 0.02$ & $0.70 \pm 0.13$ & $0.18 \pm 0.04$ & $0.95 \pm 0.09$ & $1.04 \pm 0.13$ & $0.21 \pm 0.03$ \\
\hline Heterocyclic-N & $11.03 \pm 0.32$ & $17.67 \pm 0.94$ & $15.48 \pm 0.65$ & $8.04 \pm 0.45$ & $4.91 \pm 0.46$ & $4.78 \pm 0.28$ & $6.98 \pm 0.53$ & $5.64 \pm 0.56$ & $5.51 \pm 0.32$ & $3.27 \pm 0.15$ \\
\hline Pyridines & 0.96 & 0.86 & 1.13 & 1.21 & 2.41 & 0.37 & 0.33 & 1.58 & 1.66 & 1.61 \\
\hline Quinolines & 0 & 0 & 0 & 0.94 & 1.54 & 0.34 & 0 & 0.76 & 1.14 & 0.61 \\
\hline Pyrroles & 2.94 & 5.04 & 3.48 & 0.98 & 0 & 0.04 & 0 & 0.05 & 0.06 & 0 \\
\hline Indoles & 7.13 & 11.77 & 7.71 & 4.38 & 0.80 & 3.93 & 3.94 & 3.25 & 2.03 & 0.45 \\
\hline Carbazoles & 0 & 0 & 2.95 & 0 & 0.16 & 0 & 2.65 & 0 & 0.62 & 0.58 \\
\hline Nitrile-N & $1.66 \pm 0.13$ & $2.27 \pm 0.32$ & $2.13 \pm 0.25$ & $5.62 \pm 0.43$ & $2.87 \pm 0.42$ & $1.99 \pm 0.22$ & $3.03 \pm 0.23$ & $1.75 \pm 0.30$ & $1.61 \pm 0.18$ & $1.20 \pm 0.26$ \\
\hline
\end{tabular}


(a)

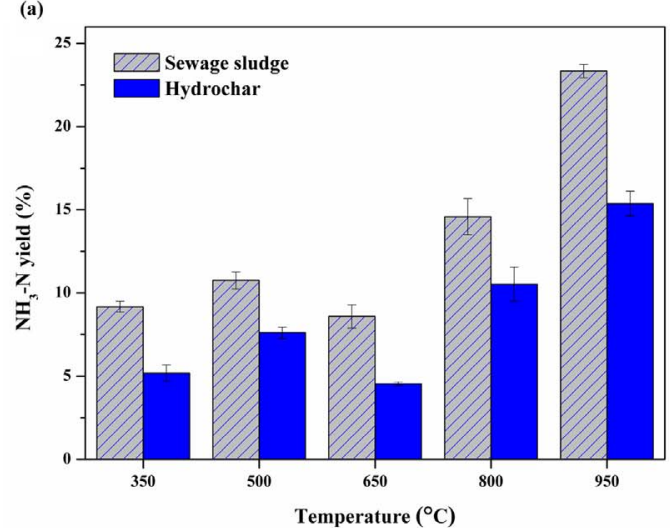

(b)

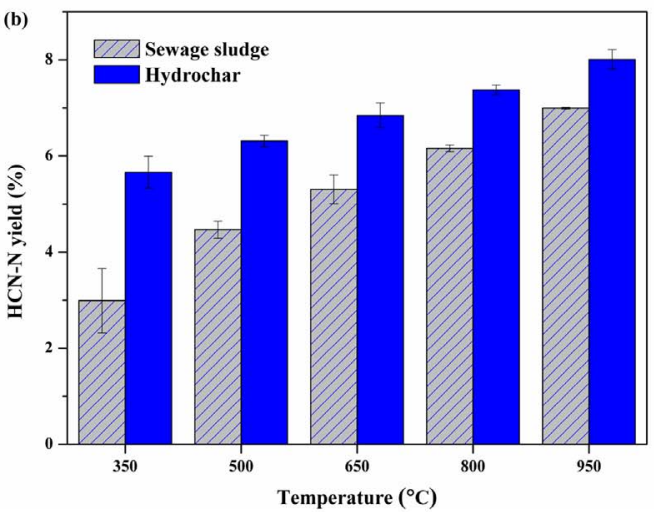

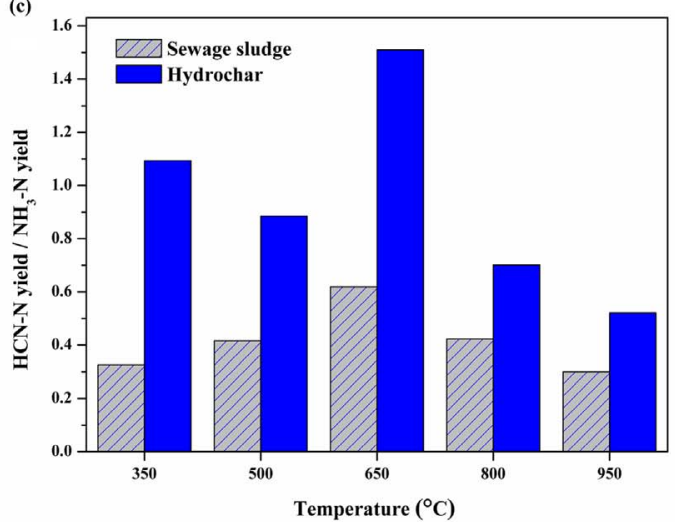

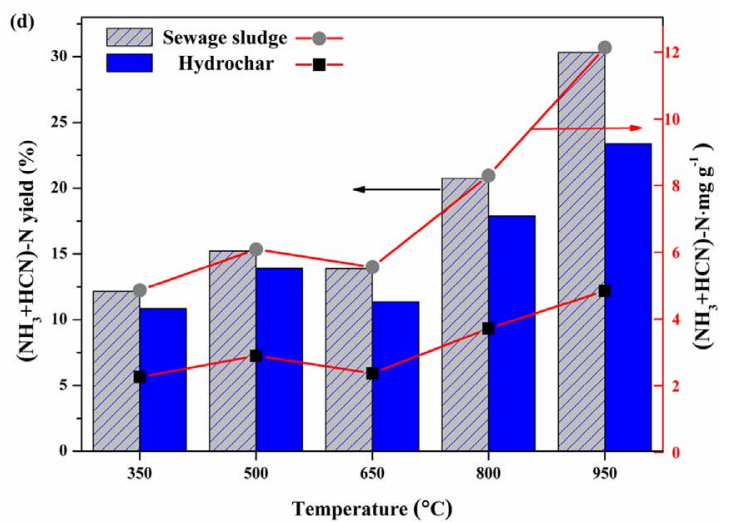

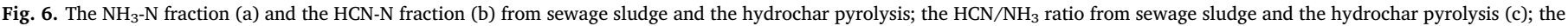
total $\left(\mathrm{NH}_{3}+\mathrm{HCN}\right)-\mathrm{N}$ yield and the amount of $\left(\mathrm{NH}_{3}+\mathrm{HCN}\right)-\mathrm{N}$ discharged from per unit sewage sludge/hydrochar (d).

$800{ }^{\circ} \mathrm{C}$ for sewage sludge tar. The different changing trends could be explained by the difference in nitrile- $\mathrm{N}$ species between sewage sludge and the hydrochar (Table S4). In the temperature range of $350-500{ }^{\circ} \mathrm{C}$, the nitrile-N compounds in sewage sludge tar were mainly benzenepropanenitrile and benzonitrile that are more thermal stable than alkyl nitriles in hydrochar tar. With increasing temperature to $650{ }^{\circ} \mathrm{C}$ and $800{ }^{\circ} \mathrm{C}$, reactive alkyl nitriles in hydrochar tar were easily cracked into small molecular nitrogen-containing gas like HCN, while benzenepropanenitrile and benzonitrile in sewage sludge tar generated more stable naphthalenecarbonitrile and anthracenecarbonitrile through polymerization or ring condensation [15,20,32].

\subsection{The nitrogen distribution in the form of $\mathrm{NH}_{3}$ and $\mathrm{HCN}$}

The effects of temperature on $\mathrm{NH}_{3}$ and $\mathrm{HCN}$ emission during sewage sludge and the hydrochar pyrolysis are shown in Fig. 6. For pyrolysis of sewage sludge, a $9.2 \%$ of $\mathrm{NH}_{3}$ yield was obtained at $350{ }^{\circ} \mathrm{C}$, which was originated from the inorganic ammonium salt and labile protein- $\mathrm{N}$ in the sewage sludge [6]. A small increase of $\mathrm{NH}_{3}$ yield from $9.2 \%$ at $350{ }^{\circ} \mathrm{C}$ to $10.8 \%$ at $500{ }^{\circ} \mathrm{C}$ was due to the primary pyrolysis of macromolecular protein-N. With further increasing temperature from $500{ }^{\circ} \mathrm{C}$ to $950{ }^{\circ} \mathrm{C}$, the second thermal cracking of tar- $\mathrm{N}$ especially pyrroles and indoles gave rise to the increase in $\mathrm{NH}_{3}$ yield from $10.75 \%$ to $23.3 \%$ $[6,9]$. The char- $\mathrm{N}$ may also release $\mathrm{NH}_{3}$ by $\mathrm{H}$ radicals reactions in char surface at temperature higher than $500{ }^{\circ} \mathrm{C}$ [18]. However, a $2.2 \%$ decrease of $\mathrm{NH}_{3}$ yield was observed at $650{ }^{\circ} \mathrm{C}$ and it was possibly associated with the catalysis decomposition of char- $\mathrm{N} / \mathrm{NH}_{3}$ by iron-containing minerals in the hydrochar $[6,33,34]$. As a comparison, $\mathrm{NH}_{3}$ yield from the hydrochar pyrolysis was much lower and increased more moderately with increasing temperature. This could be ascribed to the less inorganic ammonium salt and lower reactivity of nitrogen in the hydrochar as well as the higher stability of hydrochar tar.
In the case of HCN (Fig. 6b), its yield increased from 3\% to $7 \%$ for sewage sludge pyrolysis and increased from $5.7 \%$ to $8.0 \%$ for hydrochar pyrolysis, respectively, with increasing temperature from $350{ }^{\circ} \mathrm{C}$ to $950{ }^{\circ} \mathrm{C}$. Clearly, the HCN yield from the hydrochar pyrolysis was higher but increased slower than that from sewage sludge pyrolysis. When pyrolysis temperature was lower than $500{ }^{\circ} \mathrm{C}$, the $\mathrm{HCN}$ was reported to generate mainly from the decomposition of pyrroles and nitriles in fuel [15]. Therefore, the higher HCN yield from the hydrochar pyrolysis than sewage sludge at $350-500{ }^{\circ} \mathrm{C}$ was ascribed to higher nitriles and pyrroles contents of hydrochar than that of sewage sludge as shown in Table S1. Increasing temperature would promote the cracking of heterocyclic-N and nitrile-N for HCN release in both char and tar $[6,9]$. It was reported aromatic nitrile- $\mathrm{N}$ was higher thermal stable than both pyridinic-N and pyrrolic-N, which required higher temperature to crack into small molecular compounds [15]. This explained well why heterocyclic- $\mathrm{N}$ in the tar from sewage sludge pyrolysis declined significantly with increasing temperature from $500{ }^{\circ} \mathrm{C}$ to $950{ }^{\circ} \mathrm{C}$, while the nitriles with aromatic structure increased first and then decreased in this temperature range. Thus, it was deduced that HCN was released mainly from the cracking of heterocyclic-N involving in pyrroles, indoles and carbazoles in the range of $500-800{ }^{\circ} \mathrm{C}$ while heterocyclic- $\mathrm{N}$ and aromatic nitrile-N also favored the $\mathrm{HCN}$ release at $800-950{ }^{\circ} \mathrm{C}$. As for the tar from hydrochar pyrolysis, the nitriles were alkyl structure and decreased equally to heterocyclic- $\mathrm{N}$ in the temperature of $500-650{ }^{\circ} \mathrm{C}$, indicating the same importance of heterocyclic- $\mathrm{N}$ as nitrile-N on $\mathrm{HCN}$ release in this temperature range. With increasing temperature from $650{ }^{\circ} \mathrm{C}$ to $800{ }^{\circ} \mathrm{C}$, both heterocyclic- $\mathrm{N}$ and nitrile- $\mathrm{N}$ decreased indistinctively, suggesting dominant contribution of char- $\mathrm{N}$ to the HCN release through heterogeneous reaction [28]. Heterocyclic$\mathrm{N}$ declined remarkably compared to aromatic nitriles in the temperature range of $800-950{ }^{\circ} \mathrm{C}$, providing the evidence for contribution of heterocyclic-N to $\mathrm{HCN}$ within this temperature range. 
$\mathrm{HCN} / \mathrm{NH}_{3}$ ratio was used to evaluate the selectivity conversion of fuel-N towards $\mathrm{NH}_{3}$ or $\mathrm{HCH}$ and the result is depicted in Fig. 6c. For pyrolysis of sewage sludge, the $\mathrm{HCN} / \mathrm{NH}_{3}$ ratio was lower and less than 1 in the whole temperature range, indicating $\mathrm{NH}_{3}$ was the predominant $\mathrm{NO}_{x}$ precursor. While $\mathrm{HCN} / \mathrm{NH}_{3}$ ratio initially increased with increasing temperature at temperature range of $350-650{ }^{\circ} \mathrm{C}$ and then decreased with further increasing temperature to $950{ }^{\circ} \mathrm{C}$ [9]. The higher temperature of releasing $\mathrm{HCN}$ from heterocyclic- $\mathrm{N}$ cracking required than that of releasing $\mathrm{NH}_{3}$ and the transformation of $\mathrm{HCN}$ produced into $\mathrm{NH}_{3}$ by the hydrogenation reaction occurring on char's surface might contribute to the lower HCN yield than $\mathrm{NH}_{3}$ yield $[15,35]$. Notably, HCN/ $\mathrm{NH}_{3}$ ratio from the hydrochar pyrolysis was much higher than that of sewage sludge. This largely related to the removal of inorganic-N and labile- $\mathrm{N}$, the higher pyrrole- $\mathrm{N}$ and nitrile- $\mathrm{N}$ content in the hydrochar as well as the higher alkyl nitrile- $\mathrm{N}$ content in hydrochar tar. Another potential reason for higher $\mathrm{HCN} / \mathrm{NH}_{3}$ ratio was the suppressed transformation of $\mathrm{HCN}$ into $\mathrm{NH}_{3}$ due to cracks and fractures on the rough surface of hydrochar particle. In addition, low oxygen content of the hydrochar might also facilitate the selective transformation of fuel-N into HCN [36].

It could be seen from Fig. $6 \mathrm{~d},\left(\mathrm{NH}_{3}+\mathrm{HCN}\right)-\mathrm{N}$ yield of hydrochar (10.8-23.4\%) was much lower than that of sewage sludge (12.16-30.3\%), which was possibly associated with the enhanced catalysis conversion of pyrrole- $\mathrm{N}$ and pyridine- $\mathrm{N}$ into $\mathrm{N}_{2}$ by the higher iron-containing and calcium-containing minerals in the hydrochar [37]. Considering the much lower nitrogen content, much less $\mathrm{NO}_{x}$ precursors from hydrochar pyrolysis were expected. Then the emissions of $\mathrm{NO}_{x}$ precursors from per unit sewage sludge and hydrochar $\left(\mathrm{P}_{\mathrm{NO}}, \mathrm{mg}\right.$ $\mathrm{N} \mathrm{g}^{-1}$ ) during pyrolysis were calculated as follows:

For sewage sludge pyrolysis:

$\mathrm{P}_{\mathrm{NO} x}\left(\mathrm{mg}^{-\mathrm{N} \mathrm{g}^{-1}}\right)=\mathrm{N}_{\mathrm{Ss}} \% \times\left(\mathrm{Y}_{\mathrm{NH} 3, \mathrm{SS}}+\mathrm{Y}_{\mathrm{HCN}, \mathrm{SS}}\right)$

For the hydrochar pyrolysis:

$\mathrm{P}_{\mathrm{NO} x}\left(\mathrm{mg}^{-\mathrm{N} \mathrm{g}^{-1}}\right)=\mathrm{N}_{\mathrm{Hy}} \% \times\left(\mathrm{Y}_{\mathrm{NH} 3, \mathrm{Hy}}+\mathrm{Y}_{\mathrm{HCN}, \mathrm{Hy}}\right)$

where $Y_{\mathrm{NH} 3, \mathrm{SS}}$ and $\mathrm{Y}_{\mathrm{HCN}, \mathrm{SS}}$ represent $\mathrm{NH}_{3}$ yield and $\mathrm{HCN}$ yield from sewage sludge pyrolysis, respectively; $\mathrm{Y}_{\mathrm{NH} 3, \mathrm{Hy}}$ and $\mathrm{Y}_{\mathrm{HCN}, \mathrm{Hy}}$ are $\mathrm{NH}_{3}$ yield and HCN yield from the hydrochar pyrolysis, respectively; $\mathrm{N}_{\mathrm{SS}} \%$ and $\mathrm{N}_{\mathrm{Hy}} \%$ are the nitrogen content in sewage sludge and the hydrochar, respectively. It can be seen from Fig. $6 \mathrm{~d}, \mathrm{P}_{\mathrm{NO}}$ released from sewage sludge and the hydrochar pyrolysis ranged from $4.67 \mathrm{mg} \mathrm{g}^{-1}$ to $12.20 \mathrm{mg} \mathrm{g}^{-1}$ and from $2.25 \mathrm{mg} \mathrm{g}^{-1}$ to $4.83 \mathrm{mg} \mathrm{g}^{-1}$, respectively. This suggested that HTC pretreatment of sewage sludge reduced by $51.8-64.4 \%$ of $\mathrm{NO}_{x}$ precursors.

\subsection{The transformation of nitrogen during pyrolysis}

Combining the above analysis with related references, nitrogen conversion mechanisms during pyrolysis of both sewage sludge and corresponding hydrochar are proposed (Fig. 7) [6,9,12,37]. XPS spectra indicated that the nitrogen in sewage sludge is generally comprised of protein-N, pyrrole-N, pyridine-N and few inorganic-N [9]. Fig. 7a shows that during HTC process, inorganic-N and part of labile protein-N can be removed through deamination and some protein- $\mathrm{N}$ can be converted into more stable forms like pyrrole- $\mathrm{N}$ and pyridine-N through polymerization and cyclization $[19,20]$. In addition, dehydrogenation of some alkyl amine-N may generate alkyl nitrile-N [20]. The different nitrogen conversion behaviors are expected from the differences of nitrogen existing forms between sewage sludge and the hydrochar. Fig. 7b shows the conversion behaviors of tar-N. For sewage sludge pyrolysis, $\mathrm{NH}_{3}$ is generated from the direct cleavage of inorganic- $\mathrm{N}$, and labile protein- $\mathrm{N}$ at $350{ }^{\circ} \mathrm{C}$ [6], accompanied by the emerging of amine$\mathrm{N}$ intermediates produced from protein- $\mathrm{N}$ pyrolysis. With raising temperature to $500{ }^{\circ} \mathrm{C}$, more $\mathrm{NH}_{3}$ is produced from the cracking of labile pyrrole- $\mathrm{N}$ and pyridine- $\mathrm{N}$ and the second decomposition of amine- $\mathrm{N}$ and stable protein-N. Meanwhile, heterocyclic-N and nitrile-N in tar are produced through the dehydrogenation and polymerization reactions between nitrogenous intermediates including amine- $\mathrm{N}$ and char- $\mathrm{N}$ $[6,9]$. At $6500^{\circ} \mathrm{C}$, the metals in sewage sludge and the hydrochar catalyze the transformation from char- $\mathrm{N} / \mathrm{NH}_{3}$ into $\mathrm{N}_{2}$, lowering the $\mathrm{NH}_{3}$ release. With further increasing temperature, the enhanced secondary cracking of heterocyclic- $\mathrm{N}$ involving pyrroles, indoles and carbazoles increases the $\mathrm{NH}_{3}$ yield dominantly. Different from sewage sludge, amine- $\mathrm{N}$ in the hydrochar tar is relatively low because of the efficient removal of inorganic-N and labile protein-N by HTC, implying heterocyclic- $\mathrm{N}$ is formed mainly from the conversion of char-N. Consequently, the $\mathrm{NH}_{3}$ originated from the direct decomposition of inorganic- $\mathrm{N}$ and labile protein- $\mathrm{N}$, and from the second cracking of amine- $\mathrm{N}$ and corresponding heterocyclic- $\mathrm{N}$ for the hydrochar pyrolysis is much low.

The HCN is released mainly from decomposition of intrinsic pyrroles and nitriles in fuels at the temperature lower than $500{ }^{\circ} \mathrm{C}$ and generated from the second craking of stable heterocyclic- $\mathrm{N}$ and nitrile- $\mathrm{N}$ at higher temperature [9]. In the hydrochar tar, the dominant alkyl nitrile- $\mathrm{N}$ releases HCN mainly through a free radical mechanism when temperature is lower than $650^{\circ} \mathrm{C}$, and generates aromatic nitrile- $\mathrm{N}$ through cyclization only when temperature is higher than $800{ }^{\circ} \mathrm{C}$ [38]. For sewage sludge, nitrile- $\mathrm{N}$ with an aromatic ring is the main nitrile- $\mathrm{N}$ compounds when the temperature is lower than $650{ }^{\circ} \mathrm{C}$. With increasing temperature to $800^{\circ} \mathrm{C}$, the polymerization of nitrile- $\mathrm{N}$ with an aromatic ring leads to the apparent generation of naphthalenecarbonitrile. Then at $950{ }^{\circ} \mathrm{C}$, partial naphthalenecarbonitrile cracks into HCN and part of naphthalenecarbonitrile further generates more stable anthracenecarbonitrile. The cracking of heterocyclic-N especially pyridine- $\mathrm{N}$ also facilitates $\mathrm{HCN}$ release when temperature is higher than $650{ }^{\circ} \mathrm{C}$, [9]. Since pyridine-N content in the hydrochar tar and sewage sludge tar are very close, higher HCN yield from the hydrochar pyrolysis mainly originated from the decomposition of labile nitrile-N in the hydrochar tar.

\section{Conclusions}

In the present study, nitrogen transformation behaviors among char, tar and gas during hydrochar pyrolysis were investigated. The HTC removed inorganic-N and labile-N efficiently and converted nitrogen into more stable existing forms through deamination, dehydrogenation and polymerization. Subsequently, more nitrogen was retained in the char, and decreased amine- $\mathrm{N}$ and heterocyclic- $\mathrm{N}$ content and increased alkyl nitrile-N content in the tar from the hydrochar pyrolysis. Furthermore, iron-containing minerals concentrated in the hydrochar and the increased cracks and fractures on surface of the hydrochar facilitated the conversion of $\mathrm{NH}_{3}$ into $\mathrm{N}_{2}$. More importantly, the $\left(\mathrm{NH}_{3}+\mathrm{HCN}\right)-\mathrm{N}$ yield from the hydrochar pyrolysis was considerably lower than that from sewage sludge pyrolysis, especially at the temperature higher than $650{ }^{\circ} \mathrm{C}$. Taking account of the much lower nitrogen content of the hydrochar, the total $\left(\mathrm{NH}_{3}+\mathrm{HCN}\right)-\mathrm{N}$ emission from the hydrochar pyrolysis was only $35.6-48.2 \%$ of that from sewage sludge pyrolysis. The present study demonstrated that environmental benefit of reducing the nitrogenous pollutantS emission can be achieved by HTC of sewage sludge.

\section{Acknowledgements}

The authors gratefully acknowledge financial support for Zhengang Liu from the "100 Talents" Program of the Chinese Academy of Sciences. We also acknowledge support from Programs of International Science and Technology Corporation (Project No. 2013DFA50920), Science and Technology of Beijing (Project No. Z131100005213007), and State Natural Sciences Fund, China (Project No. 51372276, 21506236). 


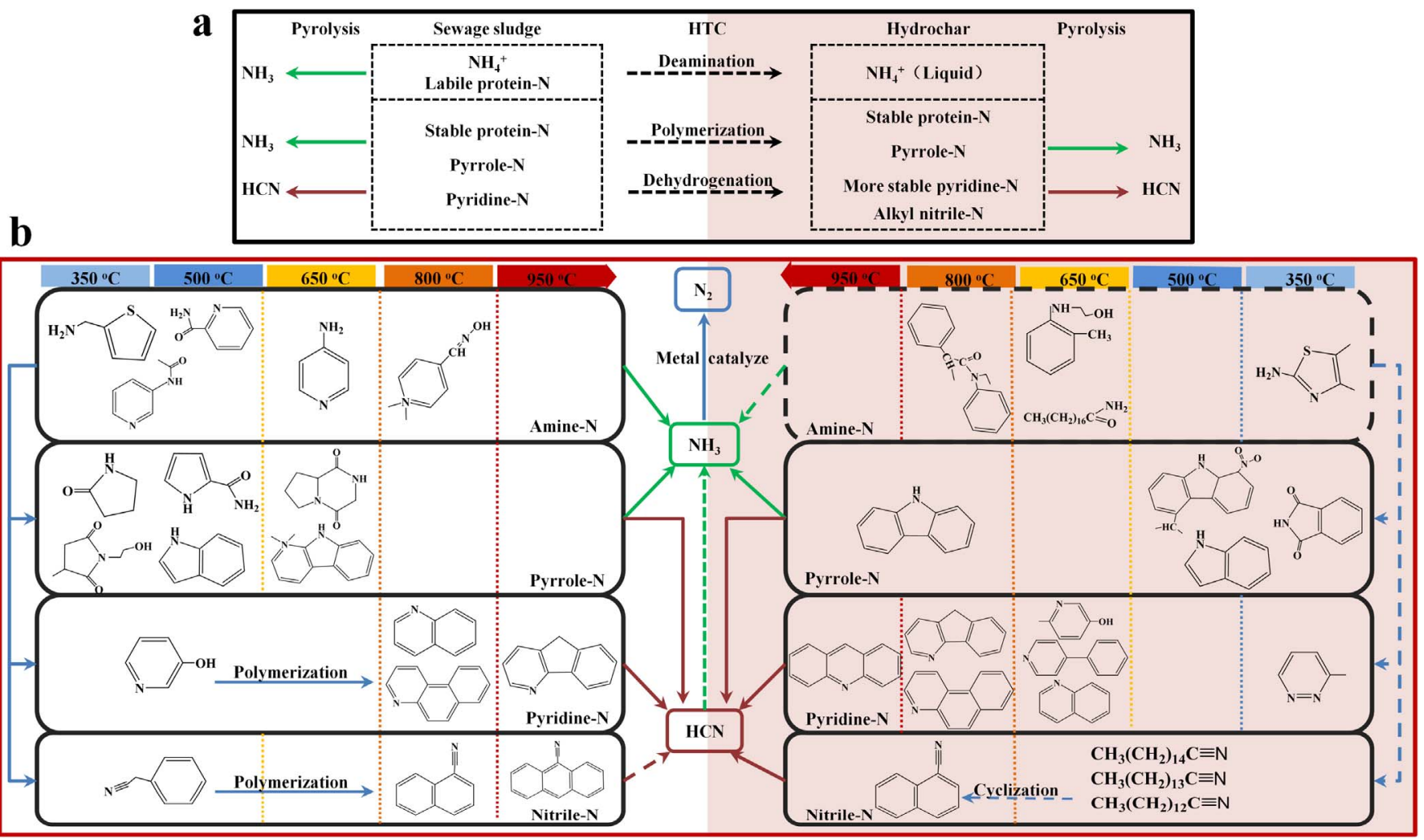

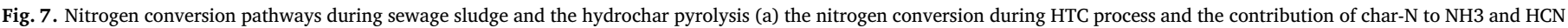
yield during pyrolysis; (b) the conversion routes of tar- $\mathrm{N}$ during pyrolysis.

\section{Appendix A. Supplementary data}

Supplementary data associated with this article can be found, in the online version, at http://dx.doi.org/10.1016/j.jaap.2017.05.017.

\section{References}

[1] G. Yang, G. Zhang, H. Wang, Current state of sludge production, management, treatment and disposal in China, Water Res. 78 (2015) 60.

[2] J. Peccia, P. Westerhoff, We should expect more out of our sewage sludge, Environ. Sci. Technol. 49 (2015) 8271.

[3] A. Kelessidis, A.S. Stasinakis, Comparative study of the methods used for treatment and final disposal of sewage sludge in European countries, Waste Manage. 32 (2012) 1186.

[4] R. Barbosa, N. Lapa, D. Boavida, H. Lopes, I. Gulyurtlu, B. Mendes, Co-combustion of coal and sewage sludge: chemical and ecotoxicological properties of ashes, J. Hazard. Mater. 170 (2009) 902.

[5] N. Skoglund, L. Bäfver, J. Fahlström, E. Holmén, C. Renström, Fuel design in cocombustion of demolition wood chips and municipal sewage sludge, Fuel Process. Technol. 141 (Part 2) (2016) 196.

[6] Y. Tian, J. Zhang, W. Zuo, L. Chen, Y. Cui, T. Tan, Nitrogen conversion in relation to $\mathrm{NH}_{3}$ and $\mathrm{HCN}$ during microwave pyrolysis of sewage sludge, Environ. Sci. Technol. 47 (2013) 3498.

[7] T. Shimizu, M. Toyono, $\mathrm{H}$. Ohsawa, Emissions of NOx and $\mathrm{N}_{2} \mathrm{O}$ during co-combustion of dried sewage sludge with coal in a bubbling fluidized bed combustor, Fuel 86 (2007) 957.

[8] M. Aznar, M.S. Anselmo, J.J. Manyà, M.B. Murillo, Experimental study examining the evolution of nitrogen compounds during the gasification of dried sewage sludge, Energy Fuels 23 (2009) 3236.

[9] L. Wei, L. Wen, T. Yang, N. Zhang, Nitrogen transformation during sewage sludge pyrolysis, Energy Fuels 29 (2015) 5088.

[10] J. Zhang, Y. Tian, J. Zhu, W. Zuo, L. Yin, Characterization of nitrogen transfor mation during microwave-induced pyrolysis of sewage sludge, J. Anal. Appl. Pyrolysis 105 (2014) 335.

[11] J. Zhang, Y. Tian, Y. Cui, W. Zuo, T. Tan, Key intermediates in nitrogen transformation during microwave pyrolysis of sewage sludge: a protein model compound study, Bioresour. Technol. 132 (2013) 57.

[12] K. Tian, W.J. Liu, T. T. Qian, H. Jiang, H.Q. Yu, Investigation on the evolution of Ncontaining organic compounds during pyrolysis of sewage sludge, Environ. Sci. Technol. 48 (2014) 10888.

[13] J.-P. Cao, L.-Y. Li, K. Morishita, X.-B. Xiao, X.-Y. Zhao, X.-Y. Wei, T. Takarada, Nitrogen transformations during fast pyrolysis of sewage sludge, Fuel 104 (2013) 1.
[14] I. Fonts, M. Azuara, G. Gea, M.B. Murillo, Study of the pyrolysis liquids obtained from different sewage sludge, J. Anal. Appl. Pyrolysis 85 (2009) 184.

[15] P. Glarborg, Fuel nitrogen conversion in solid fuel fired systems, Prog. Energy Combust. Sci. 29 (2003) 89.

[16] C. He, A. Giannis, J.-Y. Wang, Conversion of sewage sludge to clean solid fuel using hydrothermal carbonization: hydrochar fuel characteristics and combustion behavior, Appl. Energy 111 (2013) 257.

[17] C. Peng, Y. Zhai, Y. Zhu, B. Xu, T. Wang, C. Li, G. Zeng, Production of char from sewage sludge employing hydrothermal carbonization: char properties, combustion behavior and thermal characteristics, Fuel 176 (2016) 110.

[18] M. Escala, T. Zumbühl, C. Koller, R. Junge, R. Krebs, Hydrothermal carbonization as an energy-efficient alternative to established drying technologies for sewage sludge: a feasibility study on a laboratory scale, Energy Fuels 27 (2013) 454.

[19] Z. Wang, Q. Li, Z. Lin, R. Whiddon, K. Qiu, M. Kuang, K. Cen, Transformation of nitrogen and sulphur impurities during hydrothermal upgrading of low quality coals, Fuel 164 (2016) 254

[20] C. He, K. Wang, Y. Yang, P.N. Amaniampong, J.Y. Wang, Effective nitrogen removal and recovery from dewatered sewage sludge using a novel integrated system of accelerated hydrothermal deamination and air stripping, Environ. Sci. Technol. 49 (2015) 6872.

[21] P. Zhao, H. Chen, S. Ge, K. Yoshikawa, Effect of the hydrothermal pretreatment for the reduction of NO emission from sewage sludge combustion, Appl. Energy 111 (2013) 199.

[22] G.K. Parshetti, Z. Liu, A. Jain, M.P. Srinivasan, R. Balasubramanian, Hydrothermal carbonization of sewage sludge for energy production with coal, Fuel 111 (2013) 201.

[23] C. Areeprasert, F. Scala, A. Coppola, M. Urciuolo, R. Chirone, P. Chanyavanich, K. Yoshikawa, Fluidized bed co-combustion of hydrothermally treated paper sludge with two coals of different rank, Fuel Process. Technol. 144 (2016) 230.

[24] O. Kruger, A. Grabner, C. Adam, Complete survey of German sewage sludge ash, Environ. Sci. Technol. 48 (2014) 11811.

[25] E. Smidt, K. Meissl, The applicability of Fourier transform infrared (FT-IR) spectroscopy in waste management, Waste Manage. 27 (2007) 268.

[26] Z. Liu, R. Balasubramanian, A comparison of thermal behaviors of raw biomass, pyrolytic biochar and their blends with lignite, Bioresour. Technol. 146 (2013) 371.

[27] J.P. Cao, X.Y. Zhao, K. Morishita, X.Y. Wei, T. Takarada, Fractionation and identification of organic nitrogen species from bio-oil produced by fast pyrolysis of sewage sludge, Bioresour. Technol. 101 (2010) 7648.

[28] M.E. Sánchez, J.A. Menéndez, A. Domínguez, J.J. Pis, O. Martínez, L.F. Calvo, P.L. Bernad, Effect of pyrolysis temperature on the composition of the oils obtained from sewage sludge, Biomass Bioenergy 33 (2009) 933.

[29] J. Alvarez, G. Lopez, M. Amutio, M. Artetxe, I. Barbarias, A. Arregi, J. Bilbao, M. Olazar, Characterization of the bio-oil obtained by fast pyrolysis of sewage sludge in a conical spouted bed reactor, Fuel Process. Technol. 149 (2016) 169.

[30] A. Domínguez, J.A. Menéndez, M. Inguanzo, J.J. Pis, Investigations into the 
characteristics of oils produced from microwave pyrolysis of sewage sludge, Fuel Process. Technol. 86 (2005) 1007.

[31] A. Fullana, J.A. Conesa, R. Font, I. Martín-Gullón, Pyrolysis of sewage sludge: nitrogenated compounds and pretreatment effects, J. Anal. Appl. Pyrolysis 68-69 (2003) 561.

[32] M. Gao, Y. Wang, J. Dong, F. Li, K. Xie, Release behavior and formation mechanism of polycyclic aromatic hydrocarbons during coal pyrolysis, Chemosphere 158 (2016) 1.

[33] Z. Wu, Y. Sugimoto, H. Kawashima, The influence of mineral matter and catalyst on nitrogen release during slow pyrolysis of coal and related material: a comparative study, Energy Fuels 16 (2002) 451.

[34] R. Guan, W. Li, H. Chen, B. Li, The release of nitrogen species during pyrolysis of model chars loaded with different additives, Fuel Process. Technol. 85 (2004) 1025.

[35] H. Chen, T. Namioka, K. Yoshikawa, Characteristics of tarNOx precursors and their absorption performance with different scrubbing solvents during the pyrolysis of sewage sludge, Appl. Energy 88 (2011) 5032.

[36] A. Laskin, A. Lifshitz, Thermal decomposition of quinoline and isoquinoline. The role of 1-indene imine radical, J. Phys. Chem. A 102 (1998) 928.

[37] X. Zhu, S. Yang, L. Wang, Y. Liu, F. Qian, W. Yao, S. Zhang, J. Chen, Tracking the conversion of nitrogen during pyrolysis of antibiotic mycelial fermentation residues using XPS and TG-FTIR-MS technology, Environ. Pollut. 211 (2016) 20.

[38] S.T. Perry, T.H. Fletcher, M.S. Solum, R.J. Pugmire, Modeling nitrogen evolution during coal pyrolysis based on a global free-radical mechanism, Energy Fuels 14 (2000) 1094. 